\title{
DEVELOPMENT OF WORK PROCESS OF CONSTRUCTION AUTOMATION OF FOUNDATION FOR ONE-DAY HOUSING
}

\author{
$\underline{\text { Chang-Han Kim }}{ }^{1}$, Du-heon Lee ${ }^{2}$, Yeong-ho Lee ${ }^{2}$, and Kyoon-Tai Kim ${ }^{3 *}$ \\ ${ }^{1}$ Researcher, Construction Management \& Economy Research Division, \\ Korea Institute of Construction Technology, Goyang, Korea \\ ${ }^{2}$ Senior Researcher, Construction Management \& Economy Research Division, \\ Korea Institute of Construction Technology, Goyang, Korea \\ ${ }^{3}$ Senior Researcher, Ph. D., Construction Management \& Economy Research Division, \\ Korea Institute of Construction Technology, Goyang, Korea \\ *Corresponding author (ktkim@kict.re.kr)
}

\begin{abstract}
There are two essential management objectives in the construction industry: improvement of construction speed and reduction of materials used. A representative attempt to achieve these objectives, modular housing technologies have been actively applied in many developed countries, including Japan. Modular housing is a method by which a house is assembled and completed on the site based on housing modules that are manufactured in a factory. Korea, a relative newcomer to this field, has secured design and construction technologies of a structure equivalent to a detached house, and is pursuing the research and development of the design and construction technologies in order to expand its horizons.

This research aims to expand the scope of modular housing research to include the construction of the foundation, and further to establish a work process for construction to be automated. The work process established in this research will be utilized as fundamental data for the development of technologies to support 'One-Day Housing' construction, specifically automation equipment for foundation and embedded structures
\end{abstract}

Keywords: One-Day Housing, Construction Automation, Foundation, Work Process

\section{INTRODUCTION}

Since the 1990s, in line with the goals of improving the speed of construction and saving natural resources, the modular housing technique has been actively studied in developed countries, including England and Japan.

A typical modular housing construction process, both in Korea and overseas, consists of 70 percent prefabrication of the materials in a factory and 30 percent work on site, which allows constructors to reduce the construction period and improve the construction quality. However, wet construction is still used for foundation and footings, imposing restrictions on the extent to which the construction period can be reduced and the quality improved. This research aims to establish a working process for the modularization of foundation and footing work as part of research and development of Korean middle and low-story modular housing ("One-Day Housing” hereinafter), in order to maximize the efficiency of the construction process.

The subject of this research, Korean middle and low-story One-Day Housing, does not bear a lot of load itself, and also does not use a great deal of subterranean space. For this reason, we developed a working process for the modular foundation and footings for the shallow foundation.

\section{ANALYSIS OF RELATED TECHNOLOGIES}

Modular housing has already been developed to suit unique surroundings, and has gained popularity in a number of developed countries, including European countries, Japan, and the US, in which the performance of modular housing has long been proven. 
Currently, industrialized construction technologies have been applied for diverse purposes, disadvantages compared to reinforced concrete buildings in terms of living performance, such as noise between floors and fire resistance, which raises the need to develop an improved technique for Korean middle and low-story One-Day Housing. In addition, the existing technique uses wet construction for the foundation and footings, which is disadvantageous in terms of improving the quality and reducing the construction period, and thus there is an urgent need to develop a dry construction approach for the foundation and footings.

\section{DEFINITION AND CLASSIFICATION OF CONVENTIONAL FOUNDATION AND FOOTINGS}

The foundation type can be changed depending on the conditions of the ground, the size and use of the structure, and the field condition. Unlike the deep foundation (pile foundation, pier foundation, caisson foundation), the shallow foundation can be one of four different types: independent foundation, continuous foundation, combined foundation, cantilever foundation and mat foundation.

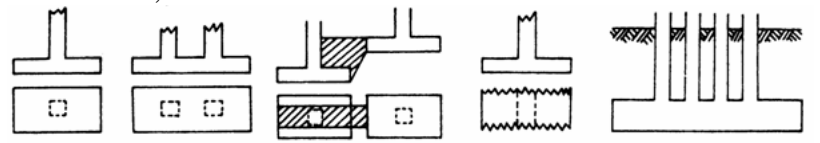

Fig. 1 Types of Shallow Foundation

The foundation should satisfy various requirements in terms of safety, construction and economy.

\section{CONSTRUCTION AND WORKING PROCESS OF FOUNDATION AND FOOTINGS}

The construction method for a shallow foundation can be divided into five steps: Slope open cut, Open Cut with Earth Retaining Wall, Ground Improvement, Artificial Ground, Current Soil.

In this research, it is assumed that modules for straight and corner parts are assembled to implement the continuous foundation. The working process for the foundation and footings can be divided into installation of the leading frame and bed excavation; placing module units by position; plumbing and alignment; assembling the module units; and other foundation construction (including slab work, if necessary). In this way, if the foundation is modularized, the work for foundation and footings becomes simple and unnecessary, leading to a reduction in the construction period.

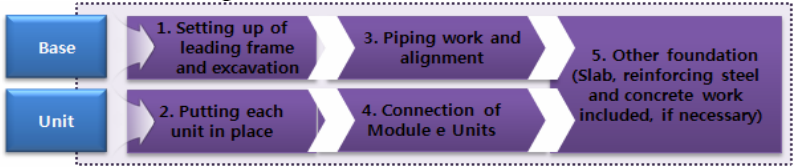

Fig. 2 Working Process of Foundation and Footings

\section{CONCLUSION}

Modular housing has been actively researched in a number of developed countries, including the European nations, Japan and the US, where it has already become popular by suitably adapting to various surroundings. Korea, a relative newcomer, has secured expertise in the appropriate design and construction techniques for a structure comparable to a single family house in size, but there are still restrictions in the extent to which the construction period can be reduced due to the use of conventional wet construction for the foundation and footings. This research established a working process for the modularization of foundation and footings, to provide a complete dry construction method for Korean middle- and low-story One-Day Housing. To do this, the shallow foundation is classified, and construction methods are analyzed to establish the working process.

\section{ACHNOWLEDGEMENT}

This research is part of the basic research of KICT (Korea Institute of Construction Technology) funded by the Ministry of Knowledge and Economy. Development of One-day Housing Construction Technology (No. 20110133)

\section{REFERENCES}

[1] K.T. Kim, a Feasibility analysis on a Modular House Construction for Urban Type Living Housing, Proceedings of the Architectural Institute of Korea, 2011

[2] http://www.joenhouse.com 